\title{
Effect of irrigation technique for removal of triple antibiotic paste on bond strength of MTA to root dentin
}

\section{Aysin DUMANI \\ Sehnaz YILMAZ \\ Oguz YOLDAS \\ Zeliha Gonca BEK}

Cukurova University, School of Dentistry, Department of Endodontics, Adana, Turkey.

Declaration of Interests: The authors certify that they have no commercial or associative interest that represents a conflict of interest in connection with the manuscript.

\section{Corresponding Author:}

Aysin Dumani

E-mail: adumani@cu.edu.tr

DOI: 10.1590/1807-3107BOR-2016.vol30.0062

Submitted: Oct 30, 2015

Accepted for publication: Mar 01, 2016

Last revision: Mar 29, 2016

\begin{abstract}
This study evaluated the bond strength of mineral trioxide aggregate (MTA) to root canal dentin after the performance of various irrigation procedures to remove triple antibiotic paste (TAP). A total of 56 single-rooted human mandibular premolars were instrumented using a rotary system to size 40 and divided randomly into a control group (no intracanal dressing) and three experimental groups (TAP application for 28 days). TAP was then removed by rinsing with $10 \mathrm{~mL} \mathrm{2.5 \%} \mathrm{NaOCl}$ using three irrigation systems (Vibringe sonic irrigation, CanalBrush, and syringe irrigation). The coronal and middle parts of root canals were then obturated with MTA. After storage for 1 week, each specimen was embedded in an acrylic block and sectioned horizontally (2-mm-thick slices) at two levels (coronal and middle). Bond strength of MTA to root canal dentin was assessed in 28 samples per group via push-out test using a universal testing machine. Data from the four groups were compared using one-way analysis of variance. Tukey's test was used for multiple comparisons. Push-out bond strength values were significantly higher in the control and Vibringe groups than in the CanalBrush and syringe irrigation groups $(p<0.001)$. TAP removal from root canals with the Vibringe irrigation system may increase the push-out bond strength of MTA compared with the use of the CanalBrush or syringe irrigation.
\end{abstract}

Keywords: Minerals; Anti-Bacterial Agents; Dental Pulp Cavity.

\section{Introduction}

Clinical regenerative endodontic procedures aim to regenerate pulp tissue in immature necrotic teeth using stem cells in the apical papilla, found near immature root apices. ${ }^{1,2}$ Triple antibiotic paste (TAP) is one of the most commonly used intracanal dressings for regeneration treatments, due to its effects against the polymicrobial flora. ${ }^{3}$ The treatment procedures involve TAP removal, followed by the placement of mineral trioxide aggregate (MTA), which has been shown to effectively support new hard-tissue formation in the apical areas of affected immature necrotic teeth. ${ }^{4}$ Despite the regenerative effects of TAP, it is acidic ${ }^{5}$ and can result in insufficient bonding to dentin ${ }^{6}$ when it is not removed thoroughly from the root canal.

Important factors for the success of various endodontic procedures are marginal adaptation and the bonding strength of endodontic 
material to root dentin to prevent apical or coronal leakage. ${ }^{7,89}$ In a recent study, Shokouhinejad et al. ${ }^{10}$ showed that significantly less force was needed to displace MTA from root dentin in samples stored under lower $\mathrm{pH}$ conditions. TAP $(\mathrm{pH}=2.9)$ is an acidic material that may have demineralizing and degrading effects, which compromise the mechanical properties of radicular dentin.,11 Moreover, the removal of creamy substances such as TAP from root canals is difficult and time consuming, and incomplete removal may impair bonding between MTA and dentin.

The effects of various irrigants and irrigation protocols for TAP removal from root canal walls have been evaluated. ${ }^{12,13}$ Berkhoff et al. ${ }^{13}$ reported that TAP was not removed effectively, with more than $80 \%$ of this material retained in the root canal system, regardless of the irrigation technique used.

Brush systems with machines (CanalBrush; Coltène/Whaledent, Langenau, Germany) and sonic irrigation systems that are used to remove debris and smear layers from root canals ${ }^{14,15}$ can be also useful for TAP removal from dentinal walls. The Vibringe system (Cavex Holland BV, Haarlem, The Netherlands), which uses sonic flow technology combined with acoustic streaming, has a cordless handpiece that delivers irrigant continuously and in a pulsatile manner directly into the root canal via a standard needle. ${ }^{16}$

In vitro studies have investigated the effects of mixing technique ${ }^{17}$ mixing solution ${ }^{18}$ technique of MTA condensation into the cavity, ${ }^{19}$ irrigation solution used in the root canal, ${ }^{9}$ and acidic environment ${ }^{10}$ on the push-out bond strength of MTA to dentin. The question is whether the use of TAP for regeneration procedures decreases the bond strength of MTA to dentin after irrigation, due to its acidity. To our knowledge, this study is the first to examine the effects of different irrigation devices on the bond strength of MTA to root canal dentin after TAP treatment.

\section{Methodology}

This study was approved by the Institutional Review Board of the University of Cukurova. In total, 56 single-rooted human mandibular premolars of similar size with complete apices were selected from a collection of teeth.

\section{Specimen preparation}

Soft tissue and calculus were removed from the root surfaces with a periodontal scaler. The teeth were verified radiographically to have single root canals. Working length was established from the apical foramen, $1 \mathrm{~mm}$ short of the length of the first instrument (size 15). Gates-Glidden drills were used in the coronal thirds of the root canals, and all canal preparations were performed at working length with a WaveOne rotary system (Dentsply Tulsa Dental Specialties, Tulsa, USA) using a large file (size 40, 0.08 taper) according to the manufacturer's instructions. In total, $5 \mathrm{~mL} 2.5 \% \mathrm{NaOCl}$ was used during canal instrumentation.

After the completion of chemomechanical preparation, teeth were divided randomly into three experimental groups $(\mathrm{n}=14$ per group) and a control group $(n=14)$. In the experimental groups, TAP was used as an intracanal dressing. TAP was prepared as a mixture of ciprofloxacin (Cipro; Biofarma, Istanbul, Turkey) $250 \mathrm{mg}$, metronidazole (Flagyl; Eczacibasi, Istanbul, Turkey) 400 mg, and minocycline (Minocycline; Ratiopharm, Ulm, Germany) $50 \mathrm{mg}$ in the proportion of 1:1:1 was as described by Hoshino et al. ${ }^{3}$ The mixture had a creamy consistency and was placed into the root canal using a \#40 Lentulo spiral. No dressing material was applied to root canals in the control group. The coronal opening of each root canal was sealed with a small cotton pellet and Cavit (ESPE, Seefeld, Germany), and the specimens were stored at $37^{\circ} \mathrm{C}$ and $100 \%$ humidity for 28 days to simulate the clinical conditions during revascularization treatment. After storage, root canals in all groups were syringe irrigated for $2 \mathrm{~min}$ with $10 \mathrm{~mL} \mathrm{2.5 \%}$ $\mathrm{NaOCl}$ using side-vented needles $(0.3 \times 25$, Endo-Top; PPH Cerkamed, Stalowa Wola, Poland). The control group and group 3 received no further treatment. In group 1, the irrigation solution was delivered and activated sonically with the Vibringe system at a flow rate of $5 \mathrm{~mL} / \mathrm{min}$, according to the manufacturer's instructions. In group 2, a CanalBrush (tip diameter, $0.25 \mathrm{~mm}$ ) in a handpiece was introduced into the root canals and activated (circumferential motion, $600 \mathrm{rpm}$ ) for the first minute of the irrigation time. 
Final irrigation with $5 \mathrm{~mL}$ distilled water was performed in all groups. The root canals were dried with paper points, and their coronal and middle sections were obturated with ProRoot MTA (Dentsply-Maillefer, Ballaigues, Switzerland), prepared according to the manufacturer's instructions. MTA was inserted into the canals with a messing gun (Dentsply-Maillefer), and pushed farther in with a plugger. A cotton pellet moistened with distilled water was placed over the MTA, and the access cavity was sealed with Cavit. The specimens were stored at $37^{\circ} \mathrm{C}$ and $95 \%$ humidity for 1 week.

After the storage period, the Cavit and cotton pellet were removed from each specimen and MTA setting was confirmed with an endodontic explorer. The tooth was then restored with a dentin-bonded resin composite (Clearfil AP-X; Kuraray Noritake Dental Inc., Okayama, Japan). Mesiodistal and buccolingual radiographs were taken to confirm complete filling of two-thirds of the root canal. Then, each specimen was embedded in an acrylic block and sectioned horizontally (2-mm thickness) at two levels (coronal and middle) with a low-speed saw (EXAKT 300 CL; Exakt Apparatbau, Norderstad, Germany), with continuous water irrigation to prevent overheating.

\section{Push-out test}

Twenty-eight dentin slices from each group were subjected to push-out tests using a universal testing machine (Testometric Company Ltd., Rochdale, Lancashire, England) with a crosshead speed of $1 \mathrm{~mm} /$ minutes. A stainless-steel device was used to align the samples to the bar used to perform the test. The bar's tip presented 1-mm-diameter cylindrical pluggers, matching the diameter of each canal third. Data were obtained in newtons (N) and bonding strength (in megapascals) was calculated by dividing force by area. Slice thickness was measured with calipers, and bonding surface area was calculated using the formula for a conical frustum: area $=\pi\left(r_{2}+r_{1}\right)\left(h^{2}+\left[r_{2}-r_{1}\right]^{2}\right)^{0.5}$, where $r_{1}$ is the apical radius and $r_{2}$ is the coronal radius of the canal diameter (in millimeters), $h$ is the thickness of the root section (in millimeters), and $\Pi$ is a constant. ${ }^{18}$ Measurements from the same root were averaged, and the statistical analysis included data from 14 samples per group.

\section{Analysis of failure mode}

After the push-out test, each specimen was examined under a stereomicroscope (SZ61; Olympus, Tokyo, Japan) at $40 \times$ magnification to determine the failure mode. Failure was categorized as adhesive failure at the MTA-dentin interface, cohesive failure within MTA, or mixed failure.

\section{Statistical analysis}

Data from the four groups were compared using one-way analysis of variance. Tukey's test was used for multiple comparisons. The significance level was set at $p=0.05$. Results are presented as means \pm standard deviations. The SPSS statistical software (version 21.0; SPSS Inc., Chicago, USA) was used for all statistical analyses.

\section{Results}

The mean push-out bond strength values in the control, Vibringe, CanalBrush, and syringe irrigation groups were 14.47, 13.96, 9.89, and 9.45 MPa, respectively (Table). Push-out bond strength did not differ significantly between the Vibringe and control groups $(p=0.997)$. Push-out bond strength values were significantly higher in the control and Vibringe groups than in the CanalBrush and syringe irrigation groups $(\mathrm{p}<0.001)$.

The distribution of failure modes is shown in Table. Adhesive failure occurred in the majority of the samples, but some samples showed cohesive and mixed failure patterns (Figure).

Table. Mean Push-out Strength and Distribution of Failure Modes.

\begin{tabular}{lcccc}
\hline \multirow{2}{*}{$\begin{array}{l}\text { Group } \\
(\mathrm{n}=14 \text { each) }\end{array}$} & $\begin{array}{c}\text { Push-out bond } \\
\text { strength (MPa) })\end{array}$ & \multicolumn{3}{c}{ Failure mode } \\
\cline { 3 - 5 } & & Adhesive & Cohesive & Mixed \\
\hline Control & $14.47 \pm 2.93^{\mathrm{a}}$ & 23 & 3 & 2 \\
Vibringe & $13.96 \pm 2.46^{\circ}$ & 24 & 3 & 1 \\
CanalBrush & $9.89 \pm 1.37^{\mathrm{b}}$ & 22 & 4 & 2 \\
$\begin{array}{l}\text { Syringe } \\
\text { irrigation }\end{array}$ & $9.45 \pm 1.75^{\mathrm{b}}$ & 23 & 3 & 2 \\
\hline
\end{tabular}

Bond strength values are presented as means \pm standard deviations. The same superscripted letters indicate homogeneous subsets. 

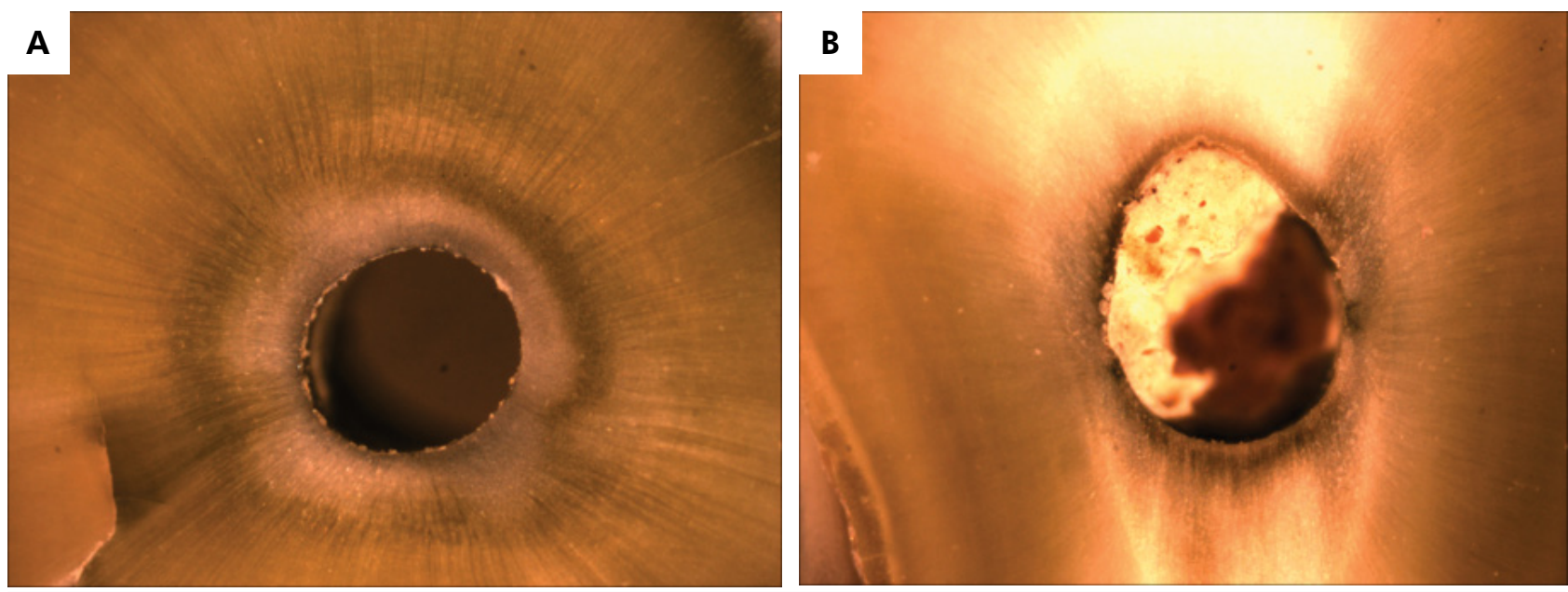

Figure. Stereomicroscopic images of (A) adhesive and (B) cohesive failure after the push-out test.

\section{Discussion}

MTA is a dental material that stimulates the odontogenic differentiation of dental pulp stem cells ${ }^{20,21}$ and harmless to the surrounding cell population, and osteoblasts, which initiate bone deposition close to the filling material. ${ }^{22}$ The biocompatibility and sealing ability of MTA may originate from physicochemical reactions between MTA and dentin. ${ }^{23}$ These properties are important in tooth-saving endodontic treatments, such as perforation repair, root-end filling, and pulp regeneration. Bonding to dentin and resistance against displacement by occlusal forces are other significant properties of MTA. ${ }^{24}$ Thus, the present study aimed to evaluate the effects of various irrigation procedures on bond strength of MTA to root canal dentin as a secondary effect of TAP removal.

In this study, the greatest mean bond strength was observed after irrigation with the Vibringe system. This finding is partly in agreement with the results of a previous study of the effects of various irrigation protocols on TAP removal, which showed that the best results were achieved by ultrasonic agitation with $1 \% \mathrm{NaOCl} .^{13}$ Sonic devices, such as Vibringe, are intended to increase the efficacy of irrigant delivery and improve canal cleanliness. Johnson et al. ${ }^{25}$ concluded that sonic irrigation devices have significantly better debridement efficacy than instrumented canal irrigation with conventional side-vented needles. The results of the present study indicate that TAP decreases the push-out bond strength of MTA to dentin. Vibringe treatment, however, did not decrease the adhesion of MTA to dentinal walls significantly. This observation may be related to the effective removal of TAP from the dentinal walls.

The CanalBrush was designed specifically for root canal cleaning; the purpose of this system is to remove debris, the smear layer, and dressing materials from root canals. Other studies have shown that the CanalBrush does not effectively remove calcium hydroxide due to its packing effect. ${ }^{26,27}$ In accordance with these findings, CanalBrush and syringe irrigation resulted in lower push-out bond strength than did the control and Vibringe treatments in this study, possibly due to insufficient removal of TAP from dentinal tubules.

A recent study investigated the effects of medicaments used in regeneration techniques on the dislocation resistance of MTA. ${ }^{9}$ It revealed no significant difference in push-out bond strength in coronal segments after the removal of TAP with minocycline or cefaclor, double antibiotic paste, and calcium hydroxide by syringe irrigation. In the present study, the effects of different irrigation systems were evaluated using only TAP with minocycline, although irrigation solutions and volumes were similar to those used in the aforementioned study. Moreover, dentin slices from the coronal and middle canal segments were prepared from each sample. Therefore, the difference in results between studies may stem from differences in experimental design. 
In the present study, most failures in all groups were adhesive. Topçuoğlu et al. ${ }^{9}$ reported mostly cohesive failure, which may occur in thick specimens. Specimens with thicker than $2 \mathrm{~mm}$ are susceptible to deformation during slicing and push-out testing. However, consensus on the appropriate thickness for push-out testing is lacking. Dentin slices with 2-mm thicknesses were used to examine push-out bond strength in the present study and in previous studies, ${ }^{8,17}$ but 1 -mm-thick slices have been used in other studies. ${ }^{28,29}$

Carbonated apatite, also known as biological apatite, represents the mineral phase of hard tissues (bone, dentin, and cementum). ${ }^{30}$ MTA has been shown to trigger the precipitation of carbonated apatite, promoting controlled mineral nucleation on dentin. Theoretically, this mechanism could initially lead to the retention of cement by dentin through a micromechanical bonding system. Insufficient removal of TAP from the root canal would cause failure of this chemical bonding. X-ray diffraction and scanning electron microscopic observations have revealed the formation of an interfacial layer with tag-like structures between MTA and dentin ${ }^{8,31}$ after 2 months. ${ }^{23}$ The specimens were stored for 1 week for MTA setting in this study because the push-out bond strength reached to a larger extent of curing after 3 days with or without humidity. ${ }^{32}$ However, the specimens were not stored for a long period before coronal restoration in the regenerative endodontic procedure to simulate clinical conditions.

As mixing technique has been shown to have an insignificant effect on push-out bond strength of white MTA, ${ }^{17}$ conventional mixing was employed for all samples in this study. Some studies have evaluated the effect of condensation technique on the bond strength of MTA to root dentin. 19,33 Manual condensation has been found to produce significantly denser root fillings, ${ }^{22}$ resulting in better adaptation to the tube walls and fewer voids in comparison with the ultrasonic method. ${ }^{33}$ In the present study, manual condensation of MTA was performed in all groups. However, irrigation of the root canal with $\mathrm{NaOCl}$ is another factor that has been found to affect bond strength, providing significantly greater push-out strength with MTA than with chlorhexidine gluconate. ${ }^{34}$ To replicate clinical practice, teeth were treated with $\mathrm{NaOCl}$ in this study. Further studies of the bond strength of MTA to dentin with the use of different irrigation solutions are needed.

Berkhoff et al. ${ }^{13}$ indicated that the EndoActivator, passive ultrasonic irrigation, EndoVac, and a syringe/Max-i-Probe needle technique did not effectively remove TAP from root canal systems, possibly because of the penetration of, and binding to, dentin. The present study did not evaluate the removal of TAP from root canals, but the higher push-out bond strength values may indicate that the Vibringe system removed TAP successfully.

\section{Conclusion}

Within the limitations of this study, the results indicated that push-out bond strength of MTA to dentin was affected by irrigation technique. Irrigation with the Vibringe system to remove TAP from root canals may increase the push-out bond strength of MTA compared with use of the CanalBrush and syringe irrigation systems.

\section{References}

1. Huang GT, Gronthos S, Shi S. Mesenchymal stem cells derived from dental tissues vs. those from other sources: their biology and role in regenerative medicine. J Dent Res. 2009;88(9):792-806. doi:10.1177/0022034509340867

2. Tziafas D, Kodonas K. Differentiation potential of dental papilla, dental pulp, and apical papilla progenitor cells. J Endod. 2010;36(5):781-9. doi:10.1016/j.joen.2010.02.006
3. Hoshino E, Kurihara-Ando N, Sato I, Uematsu H, Sato M, Kota K, et al. In-vitro antibacterial susceptibility of bacteria taken from infected root dentine to a mixture of ciprofloxacin, metronidazole and minocycline. Int Endod J. 1996;29(2):125-30. doi:10.1111/j.1365-2591.1996.tb01173.x

4. Pereira CL, Cenci MS, Demarco FF. Sealing ability of MTA, Super EBA, Vitremer and amalgam as root-end filling materials. Braz Oral Res. 2004;18(4):317-21. doi:10.1590/S1806-83242004000400008 
5. Yilmaz S, Dumani A, Yoldas O. The effect of antibiotic pastes on microhardness of dentin. Dent Traumatol. 2016;32(1):27-31. doi:10.1111/edt.12193

6. Akcay M, Arslan H, Topçuoğlu HS, Tuncay O. Effect of calcium hydroxide and double and triple antibiotic pastes on the bond strength of epoxy resin-based sealer to root canal dentin. J Endod. 2014;40(10):16637. doi:10.1016/j.joen.2014.05.006

7. Madison S, Wilcox LR. An evaluation of coronal microleakage in endodontically treated teeth. Part III. In vivo study. J Endod. 1988;14(9):455-8. doi:10.1016/S0099-2399(88)80135-3

8. Reyes-Carmona JF, Felippe MS, Felippe WT. The biomineralization ability of mineral trioxide aggregate and Portland cement on dentin enhances the push-out strength. J Endod. 2010;36(2):286-91. doi:10.1016/j.joen.2009.10.009

9. Topçuoğlu HS, Arslan H, Akçay M, Saygili G, Çakici F, Topçuoğlu G. The effect of medicaments used in endodontic regeneration technique on the dislocation resistance of mineral trioxide aggregate to root canal dentin. J Endod. 2014;40(12):2041-4. doi:10.1016/j.joen.2014.08.018

10. Shokouhinejad N, Nekoofar MH, Iravani A, Kharrazifard MJ, Dummer PM. Effect of acidic environment on the push-out bond strength of mineral trioxide aggregate. J Endod. 2014;11(2):161-6. doi:10.1016/j.joen.2009.12.025

11. Yassen GH, Chu TM, Eckert G, Platt JA. Effect of medicaments used in endodontic regeneration technique on the chemical structure of human immature radicular dentin: an in vitro study. J Endod. 2013;39(2):269-73. doi:10.1016/j.joen.2012.09.020

12. Arslan H, Capar ID, Saygili G, Uysal B, Gok T, Ertas $\mathrm{H}$ et al. Efficacy of various irrigation protocols on the removal of triple antibiotic paste. Int Endod J. 2014;47(6):594-9. doi:10.1111/iej.12194

13. Berkhoff JA, Chen PB, Teixeira FB, Diogenes A. Evaluation of triple antibiotic pasteremoval by diferent irrigation procedures. J Endod. 2014;40(8):1172-7. doi:10.1016/j.joen.2013.12.027

14. Kamel WH, Kataia EM. Comparison of the efficacy of smear clear with and without a canal brush in smear layer and debris removal from instrumented root canal using WaveOne versus ProTaper: a scanning electron microscopic study. J Endod. 2014;40(3):446-50. doi:10.1016/j.joen.2013.09.028

15. Mancini M, Cerroni L, Iorio L, Armellin E, Conte G, Cianconi L. Smear layer removal and canal cleanliness using different irrigation systems (EndoActivator, EndoVac, and passive ultrasonic irrigation): field emission scanning electron microscopic evaluation in an in vitro study. J Endod. 2013;39(11):1456-60. doi:10.1016/j.joen.2013.07.028
16. Ahmad M, Roy RA, Kamarudin AG. Observations of acoustic streaming fields around an oscillating ultrasonic file. Endod Dent Traumatol. 1992;8(5):189-94. doi:10.1111/j.1600-9657.1992.tb00241.x

17. Shahi S, Rahimi S, Yavari HR, Samiei M, Janani M, Bahari $\mathrm{M}$, et al. Effects of various mixing techniques on push-out bond strengths of white mineral trioxide aggregate. J Endod. 2012;38(4):501-4. doi:10.1016/j.joen.2012.01.001

18. Salem Milani A, Froughreyhani M, Charchi Aghdam S, Pournaghiazar F, Asghari Jafarabadi M. Mixing with propylene glycol enhances the bond strength of mineral trioxide aggregate to dentin. J Endod. 2013;39(11):1452-5. doi:10.1016/j.joen.2013.05.005

19. Aminoshariae A, Hartwell GR, Moon PC. Placement of mineral trioxide aggregate using two different techniques. J Endod. 2003;29(10):679-82. doi:10.1097/00004770-200310000-00017

20. Camilleri J. Characterization of hydration products of mineral trioxide aggregate. Int Endod J. 2008;41(5):408-17. doi:10.1111/j.1365-2591.2007.01370.x

21. Reston EG, Costa CAS. Scanning electron microscopy evaluation of the hard tissue barrier after pulp capping with calcium hydroxide, mineral trioxide aggregate (MTA) or ProRoot MTA. Aust Endod J. 2009;35(2):78-84. doi:10.1111/j.1747-4477.2008.00131.x

22. Karami B, Khayat A, Moazami F, Pardis S, Abbott P. Histological evaluation of the effect of three medicaments; trichloracetic acid, formocresol and mineral trioxide aggregate on pulpotomised teeth of dogs. Aust Endod J. 2009;35(1):18-28. doi:10.1111/j.1747-4477.2007.00112.x

23. Sarkar NK, Caicedo R, Ritwik P, Moiseyeva R, Kawashima I. Physicochemical basis of the biologic properties of mineral trioxide aggregate. J Endod. 2005;31(2):97-100. doi:10.1097/01.DON.0000133155.04468.41

24. Parirokh M, Torabinejad M. Mineral trioxide aggregate: a comprehensive literature review - Part I: chemical, physical, and antibacterial properties. J Endod. 2010;36(1):16-27. doi:10.1016/j.joen.2009.09.006

25. Johnson M, Sidow SJ, Looney SW, Lindsey K, Niu LN, Tay FR. Canal and isthmus debridement efficacy using a sonic irrigation technique in a closed-canal system. J Endod. 2012;38(9):1265-8. doi:10.1016/j.joen.2012.05.009

26. Taşdemir T, Celik D, Er K, Yildirim T, Ceyhanli KT, Yeşilyurt C. Efficacy of several techniques for the removal of calcium hydroxide medicament from root canals. Int Endod J. 2011;44(6):505-9. doi:10.1111/j.1365-2591.2011.01854.x

27. Gorduysus M, Yilmaz Z, Gorduysus O, Atila B, Karapinar SO. Effectiveness of a new canal brushing technique in removing calcium hydroxide from the root canal system: A scanning electron microscope study. J Conserv Dent. 2012;15(4):367-71. doi:10.4103/0972-0707.101909 
28. Ertas H, Kucukyilmaz E, Ok E, Uysal B. Push-out bond strength of different mineral trioxide aggregates. Eur J Dent. 2014;8(3):348-52. doi:10.4103/1305-7456.137646

29. Guneser MB, Akbulut MB, Eldeniz AU. Effect of various endodontic irrigants on the push-out bond strength of biodentine and conventional root perforation repair materials. J Endod. 2013;39(3):380-4. doi:10.1016/j.joen.2012.11.033

30. Tay FR, Pashley DH, Rueggeberg FA, Loushine RJ, Weller RN. Calcium phosphate phase transformation produced by the interaction of the portland cement component of white mineral trioxide aggregate with a phosphate-containing fluid. J Endod. 2007;33(11):1347-51. doi:10.1016/j.joen.2007.07.008

31. Reyes-Carmona JF, Felippe MS, Felippe WT. Biomineralization ability and interaction of mineral trioxide aggregate and white portland cement with dentin in a phosphate-containing fluid. J Endod. 2009;35(5):731-6. doi:10.1016/j.joen.2009.02.011

32. Gancedo-Caravia L, Garcia-Barbero E. Influence of humidity and setting time on the push-out strength of mineral trioxide aggregate obturations. J Endod. 2006;32(9):894-6. doi:10.1016/j.joen.2006.03.004

33. El-Ma'aita AM, Qualtrough AJ, Watts DC.

A micro-computed tomography evaluation of mineral trioxide aggregate root canal fillings. J Endod. 2012;38(5):670-2. doi:10.1016/j.joen.2012.01.009

34. Hong ST, Bae KS, Baek SH, Kum KY, Shon WJ, Lee $W$. Effects of root canal irrigants on the push-out strength and hydration behavior of accelerated mineral trioxide aggregate in its early setting phase. J Endod. 2010;36(12):1995-9. doi:10.1016/j.joen.2010.08.039 